\title{
Responsibility to Act Mature and Identification of Sense of Belonging through Skills Pre-Professionals (Case of the Student Teacher of EPS in Tunisia)
}

\author{
Ayman Guemri' ${ }^{1}$, Nejah Kacem ${ }^{2}$, Chokri Naffeti ${ }^{3}$, Mourad Bahloul $^{4}$ \\ ${ }^{1}$ Group for the Study of Development and Social Environment (GEDES), Faculty of Human and Social Science of Tunis, Tunis, \\ Tunisia \\ ${ }^{2}$ Higher Institute of Sport and Physical Education of Ksar Said, Manouba, Tunisia \\ ${ }^{3}$ State, Culture and Change of Society, ECUMUS, Sfax, Tunisia \\ ${ }^{4}$ Higher Institute of Sport and Education Physics Sfax, Sfax, Tunisia \\ Email:kacemnejah@gmail.com
}

How to cite this paper: Guemri, A., Kacem, N., Naffeti, C., \& Bahloul, M. (2018). Responsibility to Act Mature and Identification of Sense of Belonging through Skills Pre-Professionals (Case of the Student Teacher of EPS in Tunisia). Advances in Physical Education, 8, 129-150.

https://doi.org/10.4236/ape.2018.81013

Received: December 5, 2017

Accepted: February 25, 2018

Published: February 28, 2018

Copyright $\odot 2018$ by authors and Scientific Research Publishing Inc. This work is licensed under the Creative Commons Attribution International License (CC BY 4.0).

http://creativecommons.org/licenses/by/4.0/

\begin{abstract}
Analysis maturity of acting responsibility leads us to explain the competence "Acting as a state employee in an ethical and responsible way". This skill is more necessary in training teachers of different disciplines, including students of sports and physical education. This skill is to act on a daily basis in his class in accordance with the Regulation (rights, duties of officials, official texts). According to the training of teachers' repository, this skill is an academic skill that affects the exercise of professional responsibility and ethics. This study is to look for the effect of the practice teaching of EPS on the feeling of competence "Act in official and the State of ethical and responsible way." The French version of the Scale of measure of efficacy of trainee teachers was used to calculate these effects. Our sample is comprised of 402 trainees from the higher institute of sport and physical education of Sfax who participated voluntarily in this study after an eight-month internship in different schools of the city of Sfax. Based on our results, trainee teachers of EPS estimate have actually progressed during the teaching course of EPS with regard to jurisdiction "official and the State of ethical and responsible act". In conclusion, "while teachers may not breach the relevant civil laws, such as the Act on public education, or to a lesser extent, the law on the protection of the youth".
\end{abstract}




\section{Keywords}

Pedagogical Internship, Feeling of Competence, Work Ethic, Maturity, Sense of Belonging

\section{Introduction}

According to UNESCO (2015) "education for citizenship equips young people by providing them with the knowledge, the know-how and an understanding that will allow them to play an active, effective role in society, being enlightened citizens and critics," morally and socially responsible. Among the objectives of education for global citizenship for learners is acquirer responsible behavior from an ethical point of view, understanding the concepts of social justice and ethical responsibility and learning to apply them in the daily life. Indeed, education has the citizenship that is not one-dimensional, but rather multidimensional. There are several dimensions that are respectively, cognitive, social, emotional and behavioral. "According to UNESCO (2017), the behavioral dimension is to be effective and responsible manner at local, national and global levels to promote peace and sustainability in the world." Among the objective of this dimension is to understand the structures of global governance, rights and responsibilities, global issues and the links between the systems and the global, national and local processes, acquire and apply the critical citizenship skills, for example, critical examination, Information Technology and media, critical thinking, decision-making, problem solving, negotiation, promotion of peace and undertaking personal and social responsibilities. "Act on official State and an ethical and responsible way is the first skill of repository of training of teachers (Perrault, 2010). This skill is an academic skill that affects the exercise of professional responsibility and ethics." Professor builds relationships of mutual respect between students and him, and uses assent with discernment and in compliance with the law: Active participation in class councils and boards of education; Involvement in the project of the school and/or the contract of objectives; Implementation and use of shared resources (texts media work practices, exercises, homework, ...); Participation in disciplinary or interdisciplinary projects; Possible participation in other bodies of the institution (Board of Directors, educational Council, responsibility for the laboratory...). The goal of our research is to show effect of practice teaching of EPS on the feeling of competence "Act in official and the State of ethical and responsible way".

\section{Theoretical Approach}

\subsection{The Sense of Self-Efficacy in Teaching}

Several authors are interested in this concept. Among these authors we quote especially Albert Bandura interested the 1980s in the sense of self efficiency. The latter is part of the socio-cognitive theory (a theory that unites the Behaviorism 
and cognitivism). As part of its social cognitive theory, Bandura considers the behavior as the result of interactions between three factors represented in this Figure 1.

First, the person $(\mathrm{P})$, which is defined as the determinant cognitive that represents what we think the individual. It's the person with "these cognitions, his affects, his sense of self efficiency" Nagels (2010). The person is interacting with the behavior and the environment. Then, the behavior (C), is defined as "emotional acts and behaviour patterns". (Nagels, 2010) The behavior is interacting with the person and the environment. Finally, environmental (E) represents the characteristics of environment, "it's the social environment with its resources and constraints" (Nagels, 2010). The environment is interacting with the behavior and the person.

Therefore, from the scheme of the reciprocal determinism that fit into the social cognitive theory of Bandura (1986), it can be seen that the sense of self efficiency belongs to cognitive determinants of schema of determinism mutual. This can lead us to the concept of sense of self efficacite. Gibson and Dembo considerations (1984) the sense of self efficiency is "the belief of the teacher in its ability to influence the student's learning" (Gibson \& Dembo, 1984). According to (Nagels, 2010), there are four sources that allow you to build or modify the sense of self efficiency: active control experience, indirect experience, verbal persuasion and emotional or physiological state. Indeed, the construction of sense of self-efficacy is still performed by control shaping. According to Gist, Rosen, \& Schwoerer (1988) "the undying influences must aim to build a sense of self-efficacy to impart knowledge about the procedures and strategies. According to Burke \& Day, 1986, it is a first step in the acquisition of skills. Acquirer for the teaching skills is respectively, transversal skills, skills at the heart of the business and academic skills. The first skill academic the teaching "act in official and the State of ethical and responsible way."

\subsection{Act in Official and the State of Ethical and Responsible Way}

Act on official State and an ethical and responsible way is the first skill of repository of training of teachers (Perrault, 2010). This skill is an academic skill that affects the exercise of professional responsibility and ethics. Of after Perrault

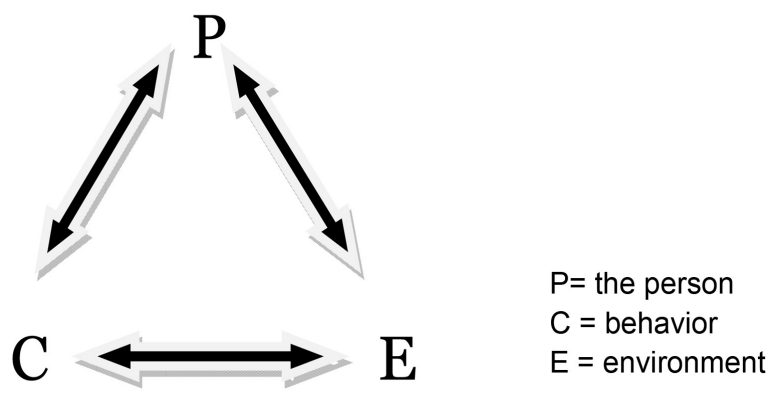

Figure 1. Scheme of the reciprocal determinism (according to the theory Social cognitive of Bandura (1986)). 
questionnaire (2008), this skill is to "register the values of the Republic in his professional practice, ensure a framework guaranteeing the security, safety and respect for all students, and Act every day in his class in accordance with the Regulation (rights, duties of officials, official texts)".

State official and an ethical and responsible way, the student teacher to be:

- respect the official instructions of the teaching of EPS.

- respect the official EPS teaching program: this program contains different cycles to teach and the different criteria and status of implementation.

- respect the rules of procedure of the school: each school has its own rules of procedure. This regulation is specific to this business, and it differs from one institution to another.

- respect the Tunisian public service act. This law is standard for all public officials, but there is currently specific status for teachers and the law of the public service in General.

- respect for the national and international conventions at the level of the rights of the child: each country has its own law on the right of the child. In Tunisia, the code for the protection of the child which is introduced in (1995), said that "every child has the right to respect for his private life, taking into account the rights and responsibilities of parents or those who are responsible", "in accordance with the law."

- respect the administrative hierarchy of the school institution. The teacher may not exceed this hierarchy. For example in writing a request to the Minister of youth and sport, this report must go through the Director of the facility in the first place and by the regional Commissioner of youth and sport, etc...).

- to respect freedom of opinion of the student because he is an actor of didactic triangle (Houssaye, 1993).

- confidential being in what concerns the information about students and their families.

- use administrative sanctions progressively and in a moderate way and without exaggeration.

- respect the student: respect the student and avoid any kind of physical or verbal violence against him. In addition, it must avoid ignorance and differentiation according to sex, social class, the region (regionalism), religion, age, grade level. According to Unicef "all children deserve a quality education based on fundamental rights and rooted on the concept of gender, will create a wave of opportunities that will have a beneficial effect on the generations to come."

- respect the student's parents: the teacher should respect the student's parents in "the meetings of parents" or in personal meetings.

- respect the educational Inspector: the pedagogical Inspector is the head teacher in teaching. The teacher must respect (the preparation of the paper, the preparation of care teaching, presence in the pedagogical days, discuss an 
inspection as part of respect and accept the instructions and the pedagogical note).

- respect the colleagues in physical education and other subjects in the sports field or in the Faculty room.

- respect the facility Director: School Director is the administrative head of education. In this context, the teacher should respect the Director (presence in meetings, respect of the time, the presence in the Council of the classes, ...). The Director is the lead of the school.

- respect the different educational and administrative frameworks in the school (supervisors, the sensor, the order desk agent, Secretaries, ...).

- respect the workers of the establishment such as the material guard, the guardian...

The teacher should respect the different actors that revolve around the provision of training in his teaching. This allows the teacher to act as an officer of State ethical and responsible for the course teaching of EPS.

\subsection{The Student Teaching in EPS}

Currently, the ISSEPS training is divided into two parts: A theoretical part, or the student is studying different theoretical material that can help in teaching, such as psychology, Physiology, the theory of physical education (TEPS), the science of education. A practical part consists of a pedagogical teaching of EPS of one school year internship in a school. This internship is an application of studied theoretical knowledge. This internship is "fruit" 3 years of academic training. According to the project on the plan of studies and plan reviews to the: "Basic license in physical Education" established by the Ministry of Youth, Sports and Education Physics (2009) "for obtaining the" license, "basic physical Education", the student must capitalize, by an average equal to or greater than $10 / 20$, UEep 2 of the semester learning unit S6. Element training camp to the teaching of the EPS UEep2 of the semester 5 is assessed by the regime of the exclusive continuous control (without second session). "Terminal control sanctioning the course of preparation for professional life (UEep 2 of the semester S6) is organized at the end of the course" (MYSEP, 2009: p. 14). The preparatory course education of the EPS belongs to the curriculum 3 era year LMD (Licence basic in physical Education for two semesters S5 and S6) It is a basic unit of education mandatory, it belongs to the module 2 "theory and practice of physical education intervention" this module contains 2 substances which are the didactics and pedagogy of the EP and the preparatory course to the teaching the EPS. The training period is 120 hours, which ends with a final exam at the end of the year where there is no of second session.

The assessment consists of two people who are: the school counselor who is a teacher of the ISSEP and framer teacher who is the teacher of the school institution responsible for supervision of the student. Evaluation of a sitting of EP criteria is mainly: the conduct of a meeting of EP, oral interview and pedagogical 
and administrative documents. The behavior of the student teacher is very important for the success of the practice teaching of EPS. According to Jellab (2004), the student teaching "this is a trial in which he is to proceed by identity compositions that are closely related to the redefinition of its role and the reconsideration of the knowledge to teach" (Jellab, 2004). The pedagogical internship represents an opportunity for the student teacher to confront the "real world of teaching" and facilitates integration in the business (Bullough et al., 2003).

All student teacher has rights and obligations it must respect in his teaching. In addition, he must have documentation and the necessary equipment to perform its task.

The trainee teacher of EPS has several rights, among which:

- To have a school where the course happens with his own choice by order of merit.

- Have a guidance of a framer of the school teacher.

- Receives teaching instructions necessary to the student in each session.

- Have some autonomy in his teaching and intervene only in an emergency.

- Have an objective assessment away from discrimination by sex, region.

- Help to integrate into the school and fit into the educational team.

- Have the information necessary to ensure the smooth running of the training course in better condition.

In return, the student teacher's homework it must respect. Of his teaching, the student teacher to:

- Avoid any sort of moral or physical violence against the student. In case of problems, it must resort to the framer teacher to find a solution. In addition, it must relatively objective, clear and credible in the assessment and avoid any kind of discrimination (by sex, region, race, ...).

- Take into account the number of weeks of work, public holidays and the blocked weeks.

- Se present in presentable sportswear and avoid all the stuff that can cause students: haircut, make-up for the girls,....

- It is forbidden to the teacher trainees to teach in absence of the framer teacher who is primarily responsible for the internship.

- The student teacher must have a theoretical course to teach in the classroom or locker room in case of bad weather.

- Refer to the official instructions and content programs of EPS.

- Take into account specificities of the institution and its cyclic distribution.

- Establish its own cyclical programming from the information collected in competition No. 1 (diagnostic assessment).

- Possibly respect the educational innovations.

In addition to these rights, the student teacher shall maintain up-to-date documentation and the necessary equipment to teach.

In our theoretical part addressed the concepts of analysis of personal efficacy as an indicator of efficiency lord of teaching situations. We started by presenting 
the personal sense of efficacy in teaching or will be presented, socio-cognitive theory of Albert Bandura and the relation between the feeling of self-efficacy and professional competence. Then, a second concept that is the "Official and the State of ethical and responsible act" or let's analyzed the various indices of this is an academic competence affecting the exercise of the professional responsibility and ethics. Finally, we closed our theoretical part by a third concept or will be presented, the student teaching, the student teacher and their right and exam. In the continuity of our methodological treatment of the various concepts discussed in the theoretical part, methodological part will complete this journey which will be interested in the presentation of the specifics of the study as well as population of mode investigation and the resulting hypotheses and objectives presentation of our problem and the statistical tool of verification of the correlation of variables analyzed.

\section{Methodology}

\subsection{Issue}

The goal of our research is to use the sense of self efficiency as an indicator to assess the efficiency of the practice teaching of EPS, bringing us to ask these questions: improving the practice teaching of EPS it the feeling of competence "official and the State of ethical and responsible act' among trainee teachers." Our issue scientific reflection of time teaching when the student (student teacher) passes north of the learner to the pole of the teaching. This transition requires the acquisition of different type of jurisdiction requires integration in pre-professional life (Figure 2).

\subsection{Investigative Method}

To address the problem of this study, it is legitimate to formulate this hypothesis: the practice teaching of EPS could improve at the student teacher skills

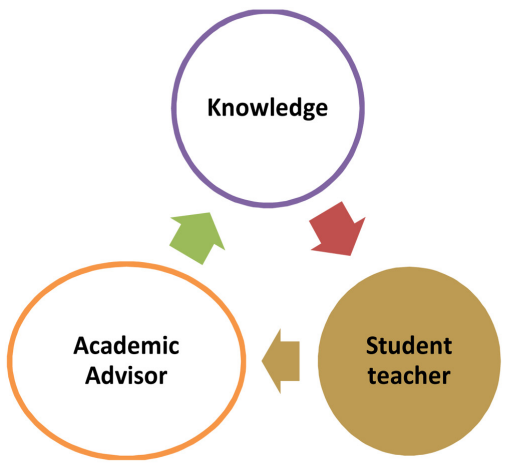

Academic context

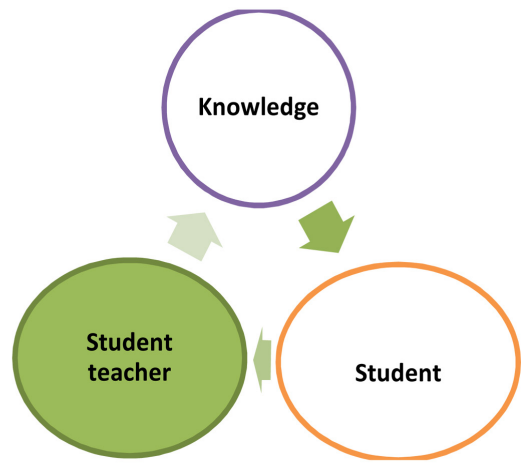

School context

Figure 2. Explanatory patterns of change of role in the teaching triangle in different contexts. 
academic. From competence "'Act on State official and an ethical and responsible way" to the levels of education of EPS. To test this hypothesis, we expect to then make a search using quantitative and qualitative methods: quantitative method is to use the questionnaire to evaluate the effect of practice teaching on the feeling of competence for the different types of skills which are respectively, academic skills, at the heart of business and cross-cutting, and subsequently determine the effect the introductory course in professional life in EPS on the sense of self efficiency of the teacher. About this questionnaire was used to determine the difference between teacher and student teacher of EPS counterparts the sense of self efficiency. The questionnaire's main function to give a larger extension to the investigation and to check statistically how far is generalizable information and previously established assumptions (Combessie 2007) at the qualitative level of method, we used semi maintenance led to the academic advisors of the ISSEP of SFAX to determine the effect of introductory to professional life in EPS on the different skills of the student teacher and take into account any suggestion to open a perspective for the future. This type of maintenance is fundamental processes of communication and human interaction that takes a conversation, more or less directed by the interviewer, on the subject of the study. This allows us to "update of psychological processes, descriptive and qualitative data and to go deeper, to take into account the motivations, the reasons underpinning the views expressed."

\section{The Questionnaire}

A questionnaire is an instrument consisting of a series of questions in order to collect information from respondents. According to Ghiglione (1987) there are three main objectives of questionnaire: first the estimation by the collection and the enumeration of data, then the Description: "it comes to remove information that describe the subjective phenomena which", "underlying objective phenomena and thus explain objective phenomena, as the motivations, the representations and opinions". Finally, the verification of the hypothesis of searching: it is here a deductive approach or the questionnaire becomes a tool to confirm or disprove a hypothesis. There are a number of assessment tools of personal efficacy of teachers, the best known and most used being the auto efficiency of teachers of Gibson and Dembo scale (1984). Perrault (2010) built its own tool that builds on the tasks and situations to which teachers have to face. This tool runs on 10 skills. These COMPEENCES are classified in 3 types of skills which are respectively the skills of transversal skills at the heart of the business and academic skills. Amongst the academic skills in Table 1, we have the skills first "Act in official and the State of ethical and responsible way" According to the methodology of Gerard (2003) to evaluate the effectiveness of training, the respondent make the mastery of these skills self-assessment that is to estimate the level of efficiency on a scale of 1 to 8 boxes ranging from "not at all effective" to "Quite effective" for each of the academic skills, to the core business and cross before and after training. Using the 10 skills, he built a training assessment scale. 
Table 1. Classification of academic skills.

\begin{tabular}{cccc}
\hline Competence & $\begin{array}{c}\text { Number of } \\
\text { Under jurisdiction }\end{array}$ & Type of jurisdiction & Field of competence \\
\hline Competence 1 & 3 & Academic skills & $\begin{array}{c}\text { the exercise of professional } \\
\text { responsibility and ethics } \\
\text { Competence 2 }\end{array}$ \\
Competence 3 & 2 & Academic skills & $\begin{array}{c}\text { the exercise of professional } \\
\text { responsibility and ethics } \\
\text { the exercise of professional } \\
\text { responsibility and ethics }\end{array}$ \\
\hline
\end{tabular}

The scale consists of 33 statements where the teacher is called upon to state its opinion on a Liker scale ranging from 1 (completely disagree) to 8 (completely agree) (see annex). According to Gerard (2003), each participant "should return to the different objectives of training, from skills in vocational training, and ask the participant to estimate for each goal its level of competence before and at the end of the training. Validation we made the tool showed us that this double questioning can be done at the same time, at the end of the training." This questionnaire is composed of 10 dimensions, represents the 10 skills, and each jurisdiction has statements according to the table below. Academic skills are represented by the 3 premiere skills, which essentially turns on the field of 'the exercise of professional responsibility and ethics.

Skills academics items are listed in the questionnaire under the following order in Table 2.

1) The pre-test:

After the introduction of the questionnaire and before the launch of the survey sample, we did a pre-test. Our first concern in the first test was to ensure as much as possible the understanding of the issues by interviewees. Also, we have applied this test on a small sample from the survey universe that has similar characteristics, but which does not belong to extract sample and having the same characteristics as the study population overall. Must the pre-test is carried out under the same conditions laid down for the investigation to check the degree of acceptability of content, the level of understanding of the issues by the population, estimate the necessary procurement. IN general the pre-test aims to test the feasibility, relevance and acceptability of the survey. In this questionnaire, we took into consideration the comments of teachers and later we changed some phrases of a few questions so they correspond to the direction of our research. We have changed the theme before and after training by before and after the internship at the top of the questionnaire. We changed in item 4 the term "register the values of the Republic in his professional practice (fight against the discrimination, secularism, equal opportunities, prevention of at-risk...)". By record values of the Tunisian Republic in his professional practice (fight against discrimination, equal opportunities, ...).

2) Data collection:

The distribution of the questionnaires will take place during May 2014 and 
Table 2. Order of the items in the scale.

\begin{tabular}{cc}
\hline $\mathrm{N}^{\circ}$ & Items \\
\hline Competence 1 & $4,6,12$ \\
Competence 2 & $7,10,11$ \\
Competence 3 & 1,2 \\
\hline
\end{tabular}

May 2015 at the ISSEP of Sfax. The questionnaires were distributed to students in 3rd year license for the free time of course. In addition, we have taken care to explain a few items to help respondents to choose the one that suits them.

3) Study population:

Each student in 3rd year EPS license must complete a student teaching of EPS (average age $21.0 \pm 1.1$ ) years) teaching in a primary school, a preparatory school (Table 3) or in a school of one session per week (Tuesday or Thursday) during the school year. Our sample is comprised of 402 student teachers of the higher Institute of sport and physical education of Sfax who participated voluntarily in this study after an eight-month internship in different schools of the city of Sfax. This course is provided by a commission composed: an academic advisor, a farmer of the school and a head of jury designated by the branch of the ISSEP internship.

4) Statistical analysis of the data:

The statistical treatment of the data collected relating to the questionnaire focused on the homogeneity, average Gain. According to Ouellet (1985), "The interest of calculation of the homogeneity or confession of variation is to have an idea of the degree of agreement among respondents." the calculations can still compare between good rates. C allows parallel shows that training helped reduce the disparity that existed at the outset. This means that learning has had an effect of "fairness", insofar as the differences in skills between the participants are reduced and that the training contributed to a more "sharing skills" Gerard (2003). According to Gerard (2003), we can calculate the effect of learning by calculating the index gain on average. The treatment of this index for each objective to have a fine enough estimate of the educational effectiveness of the training. An analysis of the effect of learning has been refined by calculating indices of gains between the two averages (before/after) training.

The interview is a method of qualitative research usually used in scientific research in human and social sciences. Maintenance is an essential tool of research and information processing.

\subsection{Maintenance}

Maintenance is a research method which allows the investigator seeks to obtain information on the attitudes, behaviors, and representatives of the population belonging to the fields of studies. According to Van Campenhoudt and Quivy (2011), "The analysis of the sense that the actors give their practices and events they are facing: their value systems, their normative bearings, their interpretations 
Table 3. Model of distribution of internship.

\begin{tabular}{cccc}
\hline & $\mathrm{M}$ & $\mathrm{F}$ & TOTAL \\
\hline Student Teaching & $\mathrm{N}=229$ & $\mathrm{~N}=173$ & $\mathrm{~N}=402$
\end{tabular}

of situations conflicting or not, their readings of their own experiences." In scientific research, there are 3 types of maintenance: maintenance led (closed), maintenance not directed (open) and semi maintenance directed. Maintenance used in this research is directed semi maintenance. The latter represents a mixture between closed and open maintenance.

\subsubsection{Population Study}

The study of study in our recherhche population consists of 10 academic advisors (average age $41.0 \pm 8.1$ ) years) with a professional 20 years experience \pm 5.2 at the ISSEP of Sfax of different sex according to the following Table 4.

\subsubsection{Interview Guide}

The guide is the set of instructions specific to support of maintenance who's role is to structure an interview as part of a memory, to get comparative items.

Using Guittet (2008), we prepare an interview guide.

Our interview guide contains the following steps:

- stand.

- present the framework of maintenance.

- introduce the objectives of maintenance and determined the relevant assumptions of the research.

- know the available time of the interviewed to have good time management.

- Approval the interviewed to make an audio recording. The recording is made using a dectaphone of a mobile telphone "Android" application.

- determine the number of questions was put in order. But it is possible to change the order of the questions according to the evolution of maintenance.

- having a clear estimation of duration of maintenance.

For the maintenance of project type for exploratory use, the guide must tolerate a margin wider freedom of speech to the interviewed in such ways should never contain questions. In addition, it is essential to ask questions on the habits, practices and behaviors rather than opinions. Something's use the term "how", "why". There is the order of the questions based on the evolution of maintenance.

\subsubsection{Content Analysis}

Content analysis is among frequently used qualitative methodologies in the social sciences and humanities. According to Berelson (1952), it is "a research technique for the description objective, systematic and quantitative of the manifest content of the communication. This means that the discourse of interviewees and answers to open questions contain information, raw data to discover the meaning in a Word to 'dissect'." According to (Coffey \& Atkinson, 1996), 
Table 4. Distribution of educational advisers gender at the ISSEP of Sfax.

\begin{tabular}{lccc}
\hline & M & F & Total \\
\hline The academic advisor & 8 & 2 & 10 \\
\hline
\end{tabular}

there are a lot of qualitative data analysis procedure. but it isn't better than the other procedure. There are only methods that are more suitable than any other given the tradition in which the researcher works". in our research content analysis is applied based on method Wanlin (2007) which consists of a reading of the interview responses and classify according to Specifiques.nen effect thematic content analysis must be objective, methodical comprehensive and quantitative.

\section{Results}

\subsection{Results of the Questionnaire}

Result: learning effect on the competence "official and the State of ethical and responsible act" of the student teacher of EPS.

According to the results in Table 5 mentioned above, is the rate of heterogeneity (coefficient of variation) has decreased after the course $\mathrm{H} 2=22.10 \%$ levels of departure $\mathrm{H} 1=32.16 \%$, but this rate remains higher than $15 \%$. This explains the practice teaching of EPS has failed to reduce the gap that existed at the beginning of the internship, which explains that learning has not had an effect of "equity". In other words, the differences in levels of skills between student teachers of EPS are not reduced later the practice teaching of EPS has not attended more "sharing" of skills.

According the results, we notice that there is a positive learning effect (average relative gain) on the sense of self efficiency with GRM $=44.85 \%$ relative gain (greater than 40\%). This indicates that student teachers of EPS feel really progress during the teaching course of EPS with regard to jurisdiction "act in official and the State of ethical and responsible way."

\subsection{Results of Maintenance}

\section{Interview on Academic Skills}

Results: interview on skill 1 "act as official of the State and in an ethical manner".

From the table of maintenance on the power 1 (see annexes), we tried to identify lexical fields that are consistent with the jurisdiction 1 "act as officer of the State and an ethical and responsible way" which are basically (respect of the) time, respect for the law, respect for the institution, respect for the student, respect for the colleague, respect for counsel, compliance, business ethics, respect for the safety of the child, respect for the discipline, respect for the administration, dress).

The figure below represents the ideas that show the frequency of use of the lexical fields of skills 1 for maintenance:

According the results in Figure 3 of interview for school advisors, we notice 
Table 5. Average relative Gain (GRM) for jurisdiction 1 "official status and ethical and responsible act" of the student teacher of EPS.

\begin{tabular}{lcccccccc}
\hline La competence & Date & \multicolumn{7}{c}{ Analyse statistique } \\
\hline & & Average & $\begin{array}{l}\text { Standard } \\
\text { deviation }\end{array}$ & CV & Erreur & GBM & GRM \\
& Front & 5.36 & 1.72 & $32.16 \%$ & 0.086 & 1.18 & $44.85 \%^{*}$ \\
Competence 1 & After & 6.54 & 1.45 & $22.10 \%$ & 0.072 & & \\
\hline
\end{tabular}

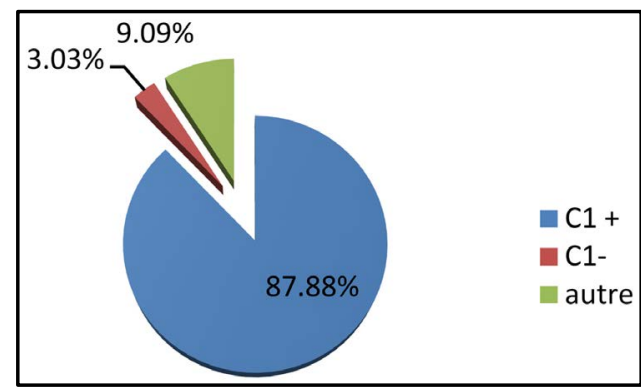

Figure 3. Distribution of responses of maintenance on jurisdiction 1 act as an ethical and responsible way and the State official.

that there is a homogeneity of response of $(87,88 \%)$ with respect to mastering the first skill "act as a public servant and the State of ethical and responsible way." So, the majority of educational advisers feel that the trainee teacher of EPS control this ability after the student teaching and subsequently the internship allows a good mastery of this skill.

\section{Discussion of the Results}

From the results, we notice that there is a positive learning effect on the sense of self efficiency with a relative gain of $44.85 \%$. (Superior has $40 \%$ ). This indicates that student teachers of EPS feel have actually progressed during the teaching course of EPS with regard to competence "Act in official and the State of ethical and responsible way."

In addition this finding is consistent with the opinion of the academic advisors regarding this skill which shows that there is a homogeneity of response of $(88,87 \%)$ with respect to mastering the first skill of repository. So the majority of educational advisers believe that the trainee teacher of EPS controls this ability after the student teaching and subsequently the internship enables a good mastery of this skill. We see that the opinion of student teachers and school advisors are parallel, which consolidates our result.

We can explain our result by several factors:

- The student teacher is a citizen first and foremost, and everyone obeys by default normally political and social authority. According to Perrier (2010) (26) "respect is a feeling one experiences to which must remain inviolable." The Professor, like any citizen, and respect to their function, must obey. 
- The dual role of the student teacher in the teaching triangle (Houssaye, 1993); the trainee teacher is a teacher in the school and a student in the higher Institute. This dual role led him to be subject to different regulations and laws such as the internal regulation of the institution, the Tunisian public service Act, the child protection act. In addition, having two roles in two didactic triangles engenders obedience to two teaching contracts, one with the student and the other with the academic advisor, which reinforces the obedience has authority and regulations resulting in jurisdiction 1 "act as ethical State employee and Manager". While teachers cannot be outside civil laws that that are specific, such as the Act on public education, or to a lesser extent, the youth protection act. In addition, according to Tenedor (2012), "The educational relationship appeals naturally to the authority" (Tenedor, 2012: p. 8). This authority is manifested to the dual role played in the didactic triangle, which implies obedience: the first based on the status embodied within the school and the other based on the hierarchy. "There is a difference between the status embodied by the teacher and the pupil based on the hierarchy".

- Theoretical training in the higher Institute can strengthen this skill. According to the project on the plan of studies and plan reviews to the: "Basic license in physical Education", there are theoretical training of the ISSEPS materials involved strongly a consolidate competence 1 for the student teacher. These materials are respectively the human rights first year LMD and 3rd year legislation LMD.

All this strengthens our result, but there's another showing is not obedience to the rules of the training in teaching, including the student teaching:

- Welbe studies (2006) show that obedience is due to the other factors such as personality, matter taught,...). Welbe (2006), obedience to the rules is often attached to several other factors, to the personality of the individual, the subject-matter.

- There are other factors also show that obedience is intrinsic. According to Welbe (2006), "The authority is thus designed as natural or innate, as a gift that some have and others don't."

Other studies also show that regulations and laws can be contradictory with different beliefs, such as the religious and ideological beliefs. What can cause the contradiction with the personal and professional identity. According to Michele (1998) there are some contradictions and their Republican inconsistencies between their ideals of equality, of secularism with neutrality and their actual practices. And more, according to Michele (1998) "these contradictions between their beliefs and their ideals, their ideals and their practices affect not only their professional identity, but also their personal identity".

In addition, the role of legislation and to the human right theoretical training may be negligible, these materials are only theoretical, may be at odds with the reality on the ground. Several authors strengthen this idea, such as Baillauques 
(2001). Darling-Hammon (2006), Desjardins and Boutet (2008), which show that there is disconnect between the theoretical training and hands-on training, despite the alternation between university courses and internship.

The assumptions of our study have been verified, this step leads us to a last to complete our research work. Some conclusion comes to close our work and a presentation of the prospects could be of extreme importance in the field course pedagogy teaching EPS gold. Promoting vocational education and acquisition of competence providing a fertile integration and a positive passage of student status to the status or the passage of transmission to pass transversely between the two poles of two didactic triangles marking a relevant development area of competence and coping with socio-educational context correlation positive and various transpositions didactic.

\section{Conclusion}

The goal of our research is to study the effect of the practice teaching on the sense of self-efficacy or the feeling of skills. These skills are in number of 10 classified into three categories: academic skills, the breasts of job skills and competencies. In addition, we find the effect of student teaching and kind on the feeling of skills.

According the results of our research on the trainee teacher of the ISSEP of Sfax EPS, it turns out that:

- Student teachers of EPS estimate actually worsened during the teaching course of EPS in the majority of the skills with similar and contradictory on the part of educational advisers.

- The pedagogical internship helped to increase the feeling of competence or sense of self efficiency of teaching.

- There is no difference between teachers facing the feeling of competence of teaching in practice teaching of EPS.

The contributions of this study translate at several levels:

- At the level of originality of research: the feeling of competence "Act official and the State of ethical and responsible way" as a academic skill is a concept that has not been studied in the context of the teaching of education Physics including the practice teaching of EPS.

- The feeling of competence "Act official and the State of ethical and responsible way" trainee is of importance, since it is an academic skill that affects the exercise of professional responsibility and ethics that allows to enter the values of the Republic in his professional practice (Perrault, 2008).

- Using two approaches of quantitative instrument (the questionnaire) and qualitative instrument. The quantitative method is to use the questionnaire for the opinion of the student teacher regarding the reliability and the efficiency of student teaching. The qualitative method is to use semi maintenance directed the ISSEP of SFAX to academic advisors to have a more objective opinion regarding the effectiveness of the induction to professional life in EP 
and offer some recommendations for the perspective for the future. All this gives us a clear idea about our study.

- Despite its relevance, our research is not without limitations: The present study is limited to only one region (Sfax), while the Tunisian people are rather heterogeneous in terms of subcultures and social classes.

While measuring the interest of our research, we can recognize some limits:

The research is limited regionally (region of Sfax) with a mixed Tunisian population which is characterized by the existence of subcultures and different social classes. Although the content of training is common to socio cultural aspect and conceptual analysis of realization of practice teaching environment may seem inevitable which the process of acquisition and development, as well as critically to management of competence acquired and transmitted knowledge. Integration is the result of the training; it is a balance of form and content of the components of psychological and cultural of the student teacher to the people which he confronts and environment which he is supposed to respond.

- The absence of repository of skill specific training to adapt to the requirement of physical education as a matter belonging to the Group of arts subjects who have well-defined features.

Given that the examination does not feature the test anymore from the contest, by a specific teaching. This would mean that those destined to the trades of teachers no longer an opportunity to reflect, from case studies concrete, on the principles of the public service, the objectives of the State in education, the implementation of principles like secularism, equality of opportunity, equality between girls and boys, on what might be a code of ethics and an ethics teacher. It would also mean that they would no longer have to wonder, before entering the trade, on the implementation of the values of the Republic in a modernity, or even a postmodern, marked, according to Max Weber, by the polytheism of the values.

For all these reasons, it is concluded that our research opens several opportunities:

- Design of a repository of skills adapted to the Tunisian people while taking into account the realities of teaching in General and specificity of physical education as a subject (Guemri et al., 2016), while insisting on the adaptation of competence "Act official and the State of ethical and responsible way" to the reality on the ground as a crucial academic skill for the good conduct of a physical education session.

- Granted a monthly allowance to each for each logic to keep the dignity and ensure the financial autonomy and subsequently act as a responsible citizen.

- The participation of teaching logic at the advises class for dealing with educational issues concerning the life of class and later propose a review and advice from individual school results for students.

- The Organization of elections commissions of the internship coordinators. This commission is composed of a student intern Coordinator for each school each coordinator is responsible for different task on sports equipment, 
control the attendance of students, organization of meetings...). This commission's task still the choice of pedagogical advisors in collaboration with the educational Department of the APS, the choice of primary schools, preparatory schools and high schools that can accommodate students and distribution of students in preparatory schools and high schools in collaboration with the Directorate of studies: this distribution is based on the choice of students with order of merit based on their averages General during the first and second year.

- Collaboration with the different actors of the educational system in a democratic atmosphere or all players participate fairly in the decision-making process, the so-called democratization of the school. These actors are, respectively, the educational staff of the school (the Director, the education advisor, supervisors,), the parents of the student, the head of school and University orientation, the school physician and medical managers and the Head of school sports to the school. More build relationships with external partners (projects artistic or cultural, linguistic exchanges, relations with the professional world...). Perrault (2008).

- Establishing a advises Pedagogical University or each trainee teacher is involved the development to the policy of the institution and the smooth running of student teaching. In the wider sense "citizenship is the set of specific social roles where the person has the opportunity to participate in groups representing their interests, ideas" (SARR, 2008).

- Giving some guidance for further research to find methods to improve the different types of skills necessary for the teaching of physical education notament competence "Act in official State and in an ethical manner and responsible", "accordingly citizenship, is the ability to recognize the ethical values required for life in common, to perform and act with the awareness of belonging to an organized social body" (SARR, 2008).

- Acquiring and applying critical citizen skills, for example the critical review, the ability to use information technology and media, critical thinking, decision-making, problem solving, negotiation, the consolidation of peace and the seizure of personal and social responsibility.

\section{References}

Baillauques, S. (2001). The Work of the Representations in the Training of Teachers. In L. Paquay (Ed.), Training Professional Teachers: What Strategies? What Skills? (pp. 41-62). Brussels: Oxford University Press.

Bandura, A. (1986). Social Foundations of Thought and Action: A Social Cognitive Theory. Englewood Cliffs, NJ: Prentice-Hall, Inc.

Berelson, B. (1952). Content Analysis in Communication Research. The Annals of the American Academy of Political and Social Science, 283, 197-198. https://doi.org/10.1177/000271625228300135

Bullough et al. (2003). Lighting Answers: Light Emitting Diode Lighting Systems. Troy, NY: National Lighting Product Information Program, Lighting Research Center, Rens- 
selaer Polytechnic Institute.

Burke, M. J., \& Day, R. R. (1986). Cumulative Study of the Effectiveness of Management Training. Journal of Applied Psychology, 71, 232-245. https://doi.org/10.1037/0021-9010.71.2.232

Coffey, A., \& Atkinson, P. (1996). Making Sense of Qualitative Data. Thousand Oaks, CA: Sage.

Combessie, J. (2007). III. The Questionnaire. In The Method in Sociology (pp. 33-44). Paris: The Discovery. https://www.cairn.info/la-methode-en-sociologie--9782707152411-page-33.htm

Darling-Hammon, D. L. (2006). Powerful Teacher Education: Lessons from Exemplary Programs. San Francisco, CA: Jossey-Bass.

Desjardins, J., \& Boutet, M. (2008). The Organization of the System of Training in the Dialogue of the Actors: For a Mediation of Knowledge. In P. Perrenoud, M. Altet, C. Lessard, \& L. Paquay (Eds.), Knowledge in Teacher Training Conflict: Between from Knowledge of Research and Knowledge from Experience (p. 155-168). Brussels: Oxford University Press.

Gerard, B. (2003). Assessment of the Effectiveness of Training, Management 2000 (Vol. 20, pp. 13-33).

Ghiglione, R. (1987). The Techniques of Social Science Surveys. Paris: Dunod.

Gibson, S., \& Dembo, M. H. (1984). Teacher Efficacy: A Construct Validation. Journal of Educational Psychology, 76, 569-582. https://doi.org/10.1037/0022-0663.76.4.569

Gist, M., Rosen, B., \& Schwoerer, C. (1988). The Influence of Training Method and Drag Age on the Acquisition of Computer Skills. Personnel Psychology, 41, 255-265. https://doi.org/10.1111/j.1744-6570.1988.tb02384.x

Guemri, A., Kacem, N., Naffeti, C., \& Bahloul, M. (2016). The Personal Sense of Efficacy as Year Indicator of Efficiency of Student Teaching of Physical Education and Sports. Advances in Physical Education, 6, 269-282. https://doi.org/10.4236/ape.2016.64028

Guittet, A. (2008). Chapter 1: Succeed in an Interview. In Maintenance: Techniques and Practices (pp. 9-14). Paris: Armand Colin.

Houssaye, J. (1993). The Educational Triangle or How to Understand the Teaching Situation. In J. Houssaye (Ed.), Pedagogy: An Encyclopedia for Today (pp. 160-163). Paris: ESF.

http://www.persee.fr/doc/refor\%200988-1824\%201994\%20num\%2017\%201\%201239\% 20t1\%200160\%200000\%202

Jellab, J. (2004). Student Teachers at the IUFM and Report to Academic and Professional Knowledge between Passage and Finalization of Content to Teach (p. 44). Research and Training.

Michele, D. (1998). The Sex of the Knowledge. Paris: Sapwood. http://eduscol.education.fr/cid47785/genre-et-pratiques-scolaires\%a0-comment-eduqu er-a-l-egalite\%a0.htm

Ministry of Youth, Sports and Education Physics (2009). Leadership Training and Research Project on the Plan of Studies and Plan Reviews to the: "Basic License in Physical Education" (p. 14).

http://www.mesrst.tn/lmd/pdf2009/sport/lf_education_physique.pdf

Nagels, M. (2010). Build a Sense of Self-Efficacy in Higher Vocational Training. In The Motivation of the Learners or How to Arouse the Desire to Learn? (p. 4). Casablanca: 4th Scientific Colloquium Organized by ESIG Casablanca.

Ouellet, G. (1985). Statistics. Theory, Examples, Problems. Sainte-Foy: The Griffon of 
Clay.

Perrault, B. (2008). Evaluation of Training by the Students of the First and Second Degrees in Teacher Training. A Survey of the Students of the Teacher. http://www.Univ-Reims.fr/formation/UFR-Instituts-et-Ecoles/l-IUFM-champagne-Ar denne/formation/Observatoire-desformations/gallery_files/site/1/90/4401/15725/15730 .pdf

Perrault, B. (2010). The Sense of Personal Effectiveness as an Indicator of the Effectiveness of Training (p. 2). An Application Is the Evaluation of the Teacher Training Conference of the Current Research in Education and Training (AREF), Geneva: University of Geneva.

Perrier, S. (2010). Man without Skill, Teaching Philosophical Editorial (p. 3). http://www.appep.NET/mat/2012/10/038lhomme_sans_competence.PDF

Sarr, S. (2008). The Citizenship Education: The Role of the School. http://www.ufapec.be/nos-analyses/2208-democratie-en-danger.html

Tenedor, M. (2012). The Authority of the Teacher: Representations to the e Reality of Practices (p. 8). Education.

UNESCO (2015). Education for Global Citizenship: Themes and Objectives of Learning. Organization of the United Nations for Education, Science and Culture.

UNESCO (2017). Network in Action: Citizens of the World Connected to Sustainable Development. The Other Part Is Called "Citizens of the World Connected to Sustainable Development: Guide for Students”. Organization of the United Nations for Education, Science and Culture. http://unesdoc.unesco.org/images/0024/002478/247837f.pdf

Van Campenhoudt, L., \& Quivy, R. (2011). Research in the Social Sciences (4th ed.). Dunod.

Wanlin (2007). Research Qualitative-Off Number-3 Conference Record and Prospective Qualitative Research (p. 252). Association for Qualitative Research.

Welbe, F. (2006). The Authority of the "Good Teacher": Assessment of Attitudes and Behaviors in Compliance with the Rules. In Proceedings of the 2006 ADMEE (p. 1). University of Luxembourg, Faculty of Language and Literature, Humanities, Arts and Education (FLSHASE). http://hdl.handle.net/10993/25606 


\section{Annexes}

Scale of measure of efficacy of trainee teachers (Perrault, 2010) translated by Guemri et al. (2016). Institution:

\begin{tabular}{|c|c|c|c|c|c|c|c|c|c|c|c|c|c|c|c|c|c|}
\hline \multirow[b]{3}{*}{1} & \multirow{3}{*}{$\begin{array}{l}\text { You are asked to estimate your level of efficacy } \\
\text { for each of the mentioned skills before and after } \\
\text { the year of internship training } \\
\text { Control the disciplinary knowledge necessary to teach }\end{array}$} & \multicolumn{8}{|c|}{ Pre-internship } & \multicolumn{8}{|c|}{ After the internship } \\
\hline & & \multicolumn{5}{|c|}{$\begin{array}{l}\text { Not everything } \\
\text { has been able }\end{array}$} & \multicolumn{3}{|c|}{$\begin{array}{l}\text { Any fact } \\
\text { at able }\end{array}$} & \multicolumn{4}{|c|}{$\begin{array}{l}\text { Not everything } \\
\text { has been able }\end{array}$} & \multicolumn{4}{|c|}{$\begin{array}{l}\text { Any fact at } \\
\text { able }\end{array}$} \\
\hline & & 1 & 2 & 3 & 4 & 5 & 6 & 7 & 8 & 1 & 2 & 3 & 4 & 5 & 6 & 7 & 8 \\
\hline 2 & Identify links between the disciplines to contribute to their articulation & 1 & 2 & 3 & 4 & 5 & 6 & 7 & 8 & 1 & 2 & 3 & 4 & 5 & 6 & 7 & 8 \\
\hline 3 & $\begin{array}{l}\text { Identify and appeal to those who can provide help and } \\
\text { support in exercise of the profession. }\end{array}$ & 1 & 2 & 3 & 4 & 5 & 6 & 7 & 8 & 1 & 2 & 3 & 4 & 5 & 6 & 7 & 8 \\
\hline 4 & $\begin{array}{l}\text { Enter the value of the Tunisian Republic in his professional practice } \\
\text { (fight against discrimination, equal opportunities...) }\end{array}$ & 1 & 2 & 3 & 4 & 5 & 6 & 7 & 8 & 1 & 2 & 3 & 4 & 5 & 6 & 7 & 8 \\
\hline 5 & $\begin{array}{l}\text { Take into account in his teaching the contributions } \\
\text { of school and teaching research. }\end{array}$ & 1 & 2 & 3 & 4 & 5 & 6 & 7 & 8 & 1 & 2 & 3 & 4 & 5 & 6 & 7 & 8 \\
\hline 6 & $\begin{array}{l}\text { Act on a daily basis in its class in compliance with the } \\
\text { Regulation (rights, duties of officials, official texts). }\end{array}$ & 1 & 2 & 3 & 4 & 5 & 6 & 7 & 8 & 1 & 2 & 3 & 4 & 5 & 6 & 7 & 8 \\
\hline 7 & Be careful to the quality of the language among students. & 1 & 2 & 3 & 4 & 5 & 6 & 7 & 8 & 1 & 2 & 3 & 4 & 5 & 6 & 7 & 8 \\
\hline 8 & Analyze its business practices. & 1 & 2 & 3 & 4 & 5 & 6 & 7 & 8 & 1 & 2 & 3 & 4 & 5 & 6 & 7 & 8 \\
\hline 9 & Formulating its vocational training needs. & 1 & 2 & 3 & 4 & 5 & 6 & 7 & 8 & 1 & 2 & 3 & 4 & 5 & 6 & 7 & 8 \\
\hline 10 & $\begin{array}{l}\text { Integrate in its practices of the mastery of oral and } \\
\text { Written language activities by students }\end{array}$ & 1 & 2 & 3 & 4 & 5 & 6 & 7 & 8 & 1 & 2 & 3 & 4 & 5 & 6 & 7 & 8 \\
\hline 11 & Being exemplary in its use of language. & 1 & 2 & 3 & 4 & 5 & 6 & 7 & 8 & 1 & 2 & 3 & 4 & 5 & 6 & 7 & 8 \\
\hline 12 & $\begin{array}{l}\text { Ensure a framework guaranteeing the safety, security and respect } \\
\text { for all students (integrities physical and moral of the students, } \\
\text { sanction, authority, justice...) }\end{array}$ & 1 & 2 & 3 & 4 & 5 & 6 & 7 & 8 & 1 & 2 & 3 & 4 & 5 & 6 & 7 & 8 \\
\hline 13 & Build a progression of learning & 1 & 2 & 3 & 4 & 5 & 6 & 7 & 8 & 1 & 2 & 3 & 4 & 5 & 6 & 7 & 8 \\
\hline 14 & $\begin{array}{l}\text { Use tic (information and communication technology) for networking } \\
\text { with colleagues ("facebook" social networks, e-mail, forum...) }\end{array}$ & 1 & 2 & 3 & 4 & 5 & 6 & 7 & 8 & 1 & 2 & 3 & 4 & 5 & 6 & 7 & 8 \\
\hline 15 & Analyze the observed performance and determine the causes of errors & 1 & 2 & 3 & 4 & 5 & 6 & 7 & 8 & 1 & 2 & 3 & 4 & 5 & 6 & 7 & 8 \\
\hline 16 & $\begin{array}{l}\text { Teaching with reference to the objectives and } \\
\text { content of formal programs of EPS. }\end{array}$ & 1 & 2 & 3 & 4 & 5 & 6 & 7 & 8 & 1 & 2 & 3 & 4 & 5 & 6 & 7 & 8 \\
\hline 17 & $\begin{array}{l}\text { Integrate ICT ((technology of information and } \\
\text { communication) in sessions with students) }\end{array}$ & 1 & 2 & 3 & 4 & 5 & 6 & 7 & 8 & 1 & 2 & 3 & 4 & 5 & 6 & 7 & 8 \\
\hline 18 & $\begin{array}{l}\text { Organize situations learning developing } \\
\text { participation and cooperation among students }\end{array}$ & 1 & 2 & 3 & 4 & 5 & 6 & 7 & 8 & 1 & 2 & 3 & 4 & 5 & 6 & 7 & 8 \\
\hline 19 & $\begin{array}{l}\text { Create a climate of confidence (attitude, respect, rules, } \\
\text { management of conflicts...) in the class supported learning }\end{array}$ & 1 & 2 & 3 & 4 & 5 & 6 & 7 & 8 & 1 & 2 & 3 & 4 & 5 & 6 & 7 & 8 \\
\hline 20 & $\begin{array}{c}\text { Choose pedagogic and didactic means (group work, media,...) } \\
\text { adapted to the learning objectives }\end{array}$ & 1 & 2 & 3 & 4 & 5 & 6 & 7 & 8 & 1 & 2 & 3 & 4 & 5 & 6 & 7 & 8 \\
\hline 21 & $\begin{array}{l}\text { To evaluate the skills of the common-base (the common base of } \\
\text { knowledge and skills this what all students should } \\
\text { know and master at the end of compulsory schooling) }\end{array}$ & 1 & 2 & 3 & 4 & 5 & 6 & 7 & 8 & 1 & 2 & 3 & 4 & 5 & 6 & 7 & 8 \\
\hline 22 & $\begin{array}{l}\text { Adapt the conduct of the meeting on the } \\
\text { basis of the effective work of the students }\end{array}$ & 1 & 2 & 3 & 4 & 5 & 6 & 7 & 8 & 1 & 2 & 3 & 4 & 5 & 6 & 7 & 8 \\
\hline
\end{tabular}




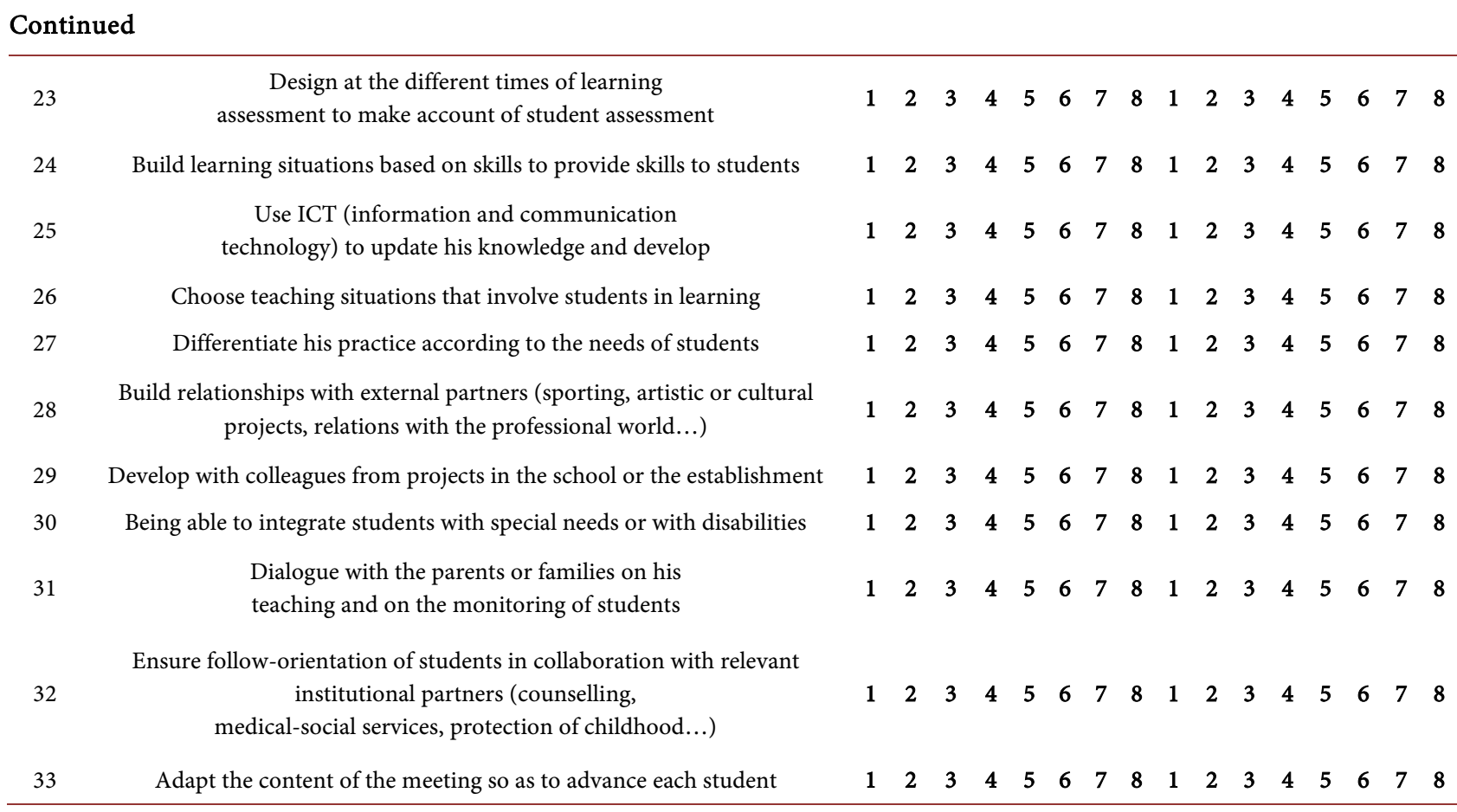

\section{Maintenance for the Pedagogical Advisor}

Skill 1: how the course teaching of eps allows-it to act in official and the State of ethical and responsible way for the Assistant teacher?

Skill 2: what is the effect of internship teaching of eps on the mastery of the French language to teach and communicate?

Skill 3: How can we master the disciplines and have a good general knowledge in a framework of internship teaching of EPS?

Skill 4: what the degree of design and implement his teaching after an internship teaching of EPS?

Skill 5: how the eps allows teaching internship-it organizes the work of the class in a session?

Skill 6: Teaching logic can take into account the diversity of students after an internship teaching of EPS?

Skill 7: what is the degree of efficacité in Evaluation of students after an internship teaching of EPS? 
Skill 8: how the pedagogical course can participate in the mastery of technologies of information and communication for teaching stagiaries?

Skill 9: How can we work as a team and cooperate with parents and school partners within a framework of internship teaching?

Skill 9: How can we develop and innovate within a framework of pedagogical internship?

Suggestion: what are your suggestions to improve skills after a teaching internship? 